\title{
多質点系の応答記録に基づく 弾塑性モード特性
}

\section{STUDY ON ESTIMATED MODAL PROPERTIES USING INELASTIC TIME-HISTORY RESPONSE RECORDS OF MDOF SYSTEMS}

益野英昌 一 -1 柴田明徳 —

キーワード

弾望性モード分解, 共分散マトリックス, 固有值解析, 多自由度モデルシステ ム

Keywords :

Estimated inelastic modal properties, Covariance matrix, Eigen value analysis, MDOF-systems
Hidemasa MASUNO — $* 1$

\section{Akenori SHIBATA - $* 2$}

Using the method of estimating modal shapes and modal amplitudes from response time-history data proposed by the authors, the statistical properties of estimated modal values are examined based on the elastic and inelastic responses of 6 mass models against 10 simulated earthquake waves. The equivalent periods corresponding to large inelastic amplitudes are also discussed.

\section{1 、はじめに}

筆者らは，先に共分散マトリクスに基づく地震応答のモード解析の 新たな方法を示し，震害建物モテルの応答に適用した ${ }^{11}{ }^{213) 。 ま ~}$ た，この方法を等質量モテル，不等質量モデルの 2 つに適用し，こ れらのモデルの弾塑性応答変位の時系列記録の共分散マトリクスか ら, 弾塑性応答時のモード形・モード振幅の変動関数スペクトルを 求め, 澺田らの方法 ${ }^{4)}$ と比較検討を行い, さらに求めた推定モード の直交性を確かめた ${ }^{51}$ 。本報では，10 波の模擬地震動による質点 系モテルの弾性及び弾塑性時系列記録から推定される, モ一ド形及 びモード振幅の特性を統計的に考察した。

\section{2. 地震応答記録による弾塑性モード解析法}

本方法は，滝澤 6） 7)，滝田らの方法 ${ }^{4)}$ を発展させ，質量分布を 考慮し，1 次，2次と低次から順にモードを掃き出す様に工夫した ものである。応答の共分散マトリクス $\left[C_{V}\right]$ から推定された推定モ 一ドマトリクス $[V]^{112)}$ を用いて, モード振幅の時間変動 $\left\{{ }_{s} a(t)\right\}$ を (1) 式のように定義する。

ここで $\left.\left[C_{V}\right]=E[\{y(t)\} y(t)\}^{T}\right] \quad$ ただしE；時間平均。

$$
\begin{aligned}
\{v(t)\} & \left.=\{\}_{1} v\right\}_{1} a(t)+\left\{_{2} v\right\}^{n} \\
& =\sum_{s=1}^{n}\left\{_{s} v\right\}_{s} a(t) \\
& \left.=[V]\}_{s} a(t)\right\}
\end{aligned}
$$

${ }_{s} a(t) ； \mathrm{~s}$ 次の時刻 $\mathrm{t}$ における推定モード振幅

$\left\{{ }_{s} v\right\} ; s$ 次の推定モードベクトル $\left(\left\{_{s} v\right\}^{T}[M]\left\{_{s} v\right\}=1\right.$ に正規化 $)$

$[V]$; 推定モードマトリクス ( $\left.\left.\left\{_{s} v\right\}[M]\right\}_{s} \nu\right\}=1$ に正規化)

$\{y(t)\} ; \mathrm{n}$ 層の基礎からの相対変位応答値（測定テータのへ クトル)

$[M]$; 質量マトリクス（対角）
推定モード $[V]$ が真のモードと同じく $[M]$ をして直交する と仮定すれば，(1) 式の両辺に前から $\left\{_{s} v\right\}^{T}[M]$ をかけると右辺で は $\left.\left\{_{s} v\right\}^{T}[M\}_{s} v\right\}$ の項のみ残り, ${ }_{s} a(t)$ が以下のように求められる ${ }^{\prime}$ 2).

$$
{ }_{s} a(t)=\frac{\left\{{ }_{s} v\right\}^{T}[M]\{y(t)\}}{\left.\{s v\}^{T}[M\}_{s} v\right\}}
$$

高次の推定モード $[V]$ を求める手順は, 以下の通りである。 (1)応答の共分散マトリクス $\left[C_{v}\right]$ を直交化し，(3) 式より求まる

推定モードマトリクス $[V]$ と (2) 式を使って 1 次の $\left\{{ }_{1} v\right\},{ }_{1} a(t)$ を求める。ここでは, $\left[C_{V}\right]$ は実対称行列なので， $[V] は[M] を$ 介さずに直交する。

$$
\left[C_{v}\right]=[V][\Lambda][V]^{T}
$$

$[\Lambda]$; 固有マトリクス

(2)推定モードが真のモードと同じく $[M]$ に直交すると仮定し，

$\{y(t)\}$ から 1 次成分を取り去った值 $\left\{y^{\prime}(t)\right\}=\{y(t)\}-\{1 v\}_{1} a(t)$ を求 め, $\left\{y^{\prime}(t)\right\}$ 共分散マトリクス $\left[C_{V}^{\prime}\right]$ を直交化して，推定モ一 ド $\left[V^{\prime}\right]$ を求める。

(3)推定モード $\left[V^{\prime}\right] よ り （ 2 ）$ 式を使って最大固有值に対応する $\left\{v_{1} v^{\prime}\right\},{ }_{1} a^{\prime}(t)$ ( $\lambda^{\prime}$ が最大の時のモ一ド) を求める。1 次振動 成分は(2)の操作で除かれているので，2次振動成分が最大固 有值に相当する。よって $\left\{v_{1} v^{\prime}\right\},{ }_{1} a^{\prime}(t)$ が, 2 次モードの $\left\{{ }_{2} v\right\}$, ${ }_{2} a(t)$ に相当すると考えられる。

(4) $\{y(t)\}$ から 1 次, 2 次成分を取り去った値, $\left\{y^{\prime \prime}(t)\right\}=\left\{y^{\prime}(t)\right\}-\left\{{ }_{1} v^{\prime}\right\}_{1} a^{\prime}(t)$ を求める。

以下同様に，n次モードまで順次求める。 これをモード減算法と呼ぶ。等質量モテル（モテル 1 ）の場合 は, モード减算法の場合と $\{y(t)\}$ の共分散マトリクス $\left[C_{V}\right]$ より

(3)式で一挙に求めた場合の推定モードが一致する。
1 仙台第二工業高等学校 教諭 ·博士 (工学)

( $983-0042$ 仙台市官城野区東宮城野3-1)

*2 東北大学 名兴教授, 東北文化学園大学 教授.工博
*1 Instructor, Sendai Second Technical High School, Dr. Eng.

*2 Prof. Emeritus, Tohoku Univ., Prof., Tohoku Bunka Gakuen Univ., Dr. Eng. 


\section{3. 数値モデルによる検討}

模擬地震波 10 波による店答記録（弾性・弾塑性） $\{y(t)\}$ から， 推定モード $[V]$ 及びモード振幅の時間変動 $\left\{{ }_{s} a(t)\right\}$ を求め, 検討を行 つた。模擬地震波の作成法は文献 8）による。模擬地震波 10 波の 最大加速度の平均値は $405.6 \mathrm{gal}$, 変動係数は 0.09 , 継続時間は 40.96 秒である。 $\left[C_{V}\right]$ の評価時間は地震動の継続時間とした。

\section{1 解析モテル}

解析モテルは，図 1 に示すような等質量分布（モデル1）及び， 不等質量分布（モデル 2）で1次モード逆三角形分布となる 6 質点 せん断型モデルであり，1 次弹性周期は両モデルとも 0.6 秒，2次， 3 次の弹性周期は表 1 に示した。而力分布は $\mathrm{Ai}$ 分布, ベースシャは 0.4 とした。履歷特性は, バイリニア型とし，バイリニア係数 1\%, 减衰特性は質量比例型とした。1 次の初期减衰 h, は $5 \%$ とした。質 量比例型减衰による地震応答記録には高次のモードが多く含まれる ので，剛性比例型减衰より高次の分離がうまくいく9。

\section{2 地震応答記録 $\{y(t)\}$}

模擬地震動 10 波による 2 種類の解析モデルの，地震応答計算值 （弾性・弾塑性）合計 40 種類の $\{y(t)\}$ を用いた。

弹塑性応答では，各層塑性率の平均值は，モテル 1 では2. 32, モテ ル 2 では2. 54, 変動係数はそれぞれ0.28，0.27となっている。

\section{3 推定モード $[V]$ の性質}

地震応答記録 $\{y(t)\}$ について求めた推定モード $[V]$ の平均値とそ の変動係数をモデこことに表 2 に示す。なお, 表 2 での各モードは, 最下層の元を 1.00 として表し検討した。また比較のため,このモデ ルの弾性時の固有值解析により求めた固有モ一ドを真のモードとし て示した。

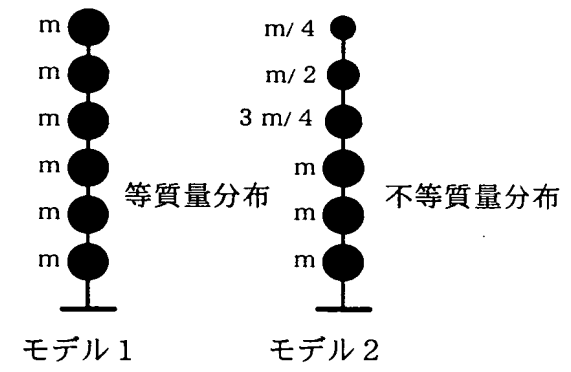

図 1. 解析モデル a) 弾性推定モート $[V]$

弾性推定モードと真のモードとの違いを検討した。全ての弾性推 定モードとも真のモードの値に近く, 最も離れた場合でも, 真のモ 一ドの值の 1 割程度の違いである。1 次の推定モードについては, 各地震波とも, 真のモードと $1 \%$ 以下の違いである。変動係数も 1 次のほうが， 2 次， 3 次の変動倸数より，1标少なくなっている。 モテルによる違いでは，モデル 2 より，モテル 1 のほうが, 真のモ 一ドに近く，変動係数が小さい。

b) 弾塑性推定モート $[V]$

推定 1 次モードを真の 1 次モードと比較すると, 真のモードと最 大で 1 割程度の違いで類似している。

高次モードでは，モテル 1 の 2 次，3次モード形とモテル 2 の 2 次モード形が真のモード形に類似しているが，モデ 2 の 3 次モー ド形は，真のモード形と異なっている。

弾塑性推定モードの変動係数の大小という観点から見ると，低い 次数の推定モードの方が, 変動倸数が小さい。また, モテル 2 より, モテル 1 が, 変動係数が小さい。

c) 推定モート $[V]$ の直交性

得られた推定モード $[V]$ の質量マトリクス $[M] に$ 対する直交性を 調べた。すなわち非対称項 $\left.\{v\}^{T}[M] h_{s} v\right\} \quad(r \neq s)$ の值がどれだ け0に近いかを検討した。なお，ここでの $\left\{\left\{_{s} v\right\} は\left\{{ }_{s} v\right\}[M\}_{s} v\right\}=1 に$ 正規化している。いずれの推定モード $[V] に$ 対しても非対角項の值は,

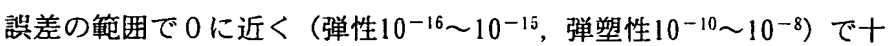
分に数值的な直交性が示される。さらに，10波それぞれの地震応 答記録による推定モードの平均値においても，非対角項が，10-1 程 度で大まかな直交性を示している。
表 1.スペクトルのピーク値, 等価線形化による各次の固有周期（秒）

\begin{tabular}{|c|c|c|c|c|}
\hline & & 1次 & 2次 & 3次 \\
\hline \multirow{5}{*}{ モデル 1} & 玉デルの周期 & 0.600 & 0.245 & 0.155 \\
\hline & スペクトルのピーク(弾性) & 0.594 & 0.248 & 0.153 \\
\hline & スペクトルのピーク(弾塑性) & 0.594 & 0.248 & 0.152 \\
\hline & 等価線形化周期 1 & 0.914 & 0.373 & 0.236 \\
\hline & 等価線形化周期 2 & 0.764 & 0.312 & 0.197 \\
\hline \multirow{5}{*}{ モデル 2} & 玉デルの周期 & 0.600 & 0.287 & 0.192 \\
\hline & スペクトルのピーク(弾性) & 0.594 & 0.286 & 0.191 \\
\hline & スペクトルのピーク(弾塑性) & 0.594 & 0.288 & 0.190 \\
\hline & 等価線形化周期 1 & 0.956 & 0.458 & 0.306 \\
\hline & 等価線形化周期 2 & 0.800 & 0.383 & 0.256 \\
\hline
\end{tabular}

表 2. 真のモード, 推定モード $[\mathrm{V}]$ （最下層の元を 1.00 として表現）

\begin{tabular}{|c|c|c|c|c|c|c|c|c|c|c|c|c|c|c|c|}
\hline & \multicolumn{3}{|c|}{ 真のモート } & \multicolumn{6}{|c|}{ 弾性推定モ一ト[V] } & \multicolumn{6}{|c|}{ 彈塑性推定モ一F[V] } \\
\hline & \multirow{2}{*}{1 次 } & \multirow{2}{*}{2 次 } & \multirow{2}{*}{3 次 } & \multicolumn{2}{|c|}{ 1次 } & \multicolumn{2}{|c|}{ 2资 } & \multicolumn{2}{|c|}{ 3冾 } & \multicolumn{2}{|c|}{ 1冾 } & \multicolumn{2}{|c|}{ 2次 } & \multicolumn{2}{|c|}{ 3次 } \\
\hline & & & & & 変動任数 & & 变動係数 & & 变動係数 & & 变動係数 & & 变動係数 & & 变動係数 \\
\hline \multirow{6}{*}{$\mid \begin{array}{c}モ \\
\vec{F} \\
ル \\
1\end{array}$} & 6.00 & -2.75 & 1.10 & 5.95 & 0.006 & -2.58 & 0.02 & 1.05 & 0.04 & 6.57 & 0.33 & -1.54 & 0.44 & 1.87 & 0.72 \\
\hline & 5.00 & 0.00 & -1.65 & 4.96 & 0.005 & -0.04 & 0.25 & -1.50 & 0.04 & 5.54 & 0.30 & -0.22 & 0.88 & -1.67 & 0.64 \\
\hline & 4.00 & 1.50 & -0.90 & 3.97 & 0.004 & 1.38 & 0.02 & -0.89 & 0.02 & 4.42 & 0.29 & 0.76 & 0.67 & -1.56 & 0.94 \\
\hline & 3.00 & 2.00 & 0.55 & 2.99 & 0.003 & 1.89 & 0.01 & 0.44 & 0.08 & 3.21 & 0.25 & 1.23 & 0.36 & 0.25 & 2.46 \\
\hline & 2.00 & 1.75 & 1.30 & 1.99 & 0.002 & 1.70 & 0.01 & 1.21 & 0.03 & 2.05 & 0.15 & 1.32 & 0.21 & 0.99 & 0.45 \\
\hline & 1.00 & 1.00 & 1.00 & 1.00 & 0.000 & 1.00 & 0.00 & 1.00 & 0.00 & 1.00 & 0.00 & .00 & 0.00 & 1.00 & 0.00 \\
\hline
\end{tabular}

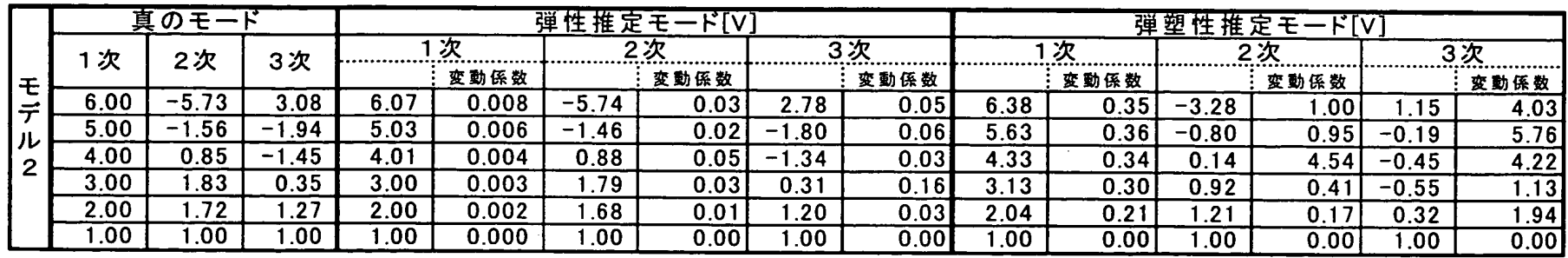




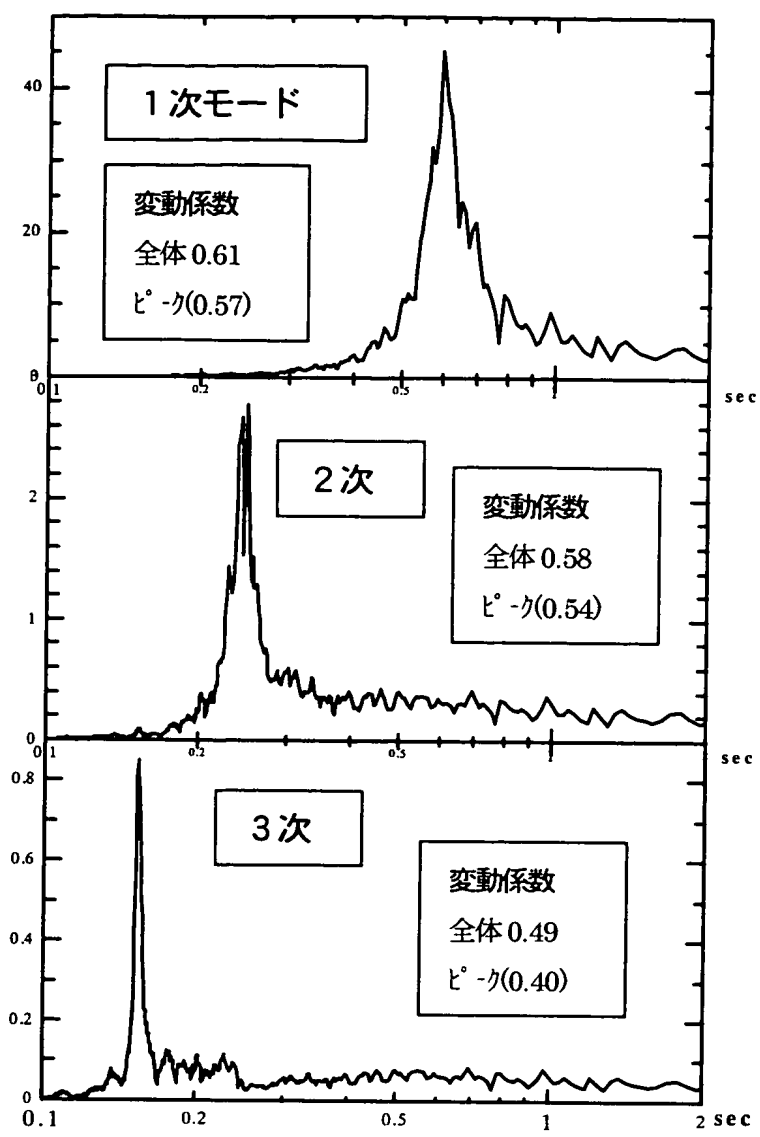

図2.モード振幅のスペクトル

[弾性，モデル 1,10 波の平均值]

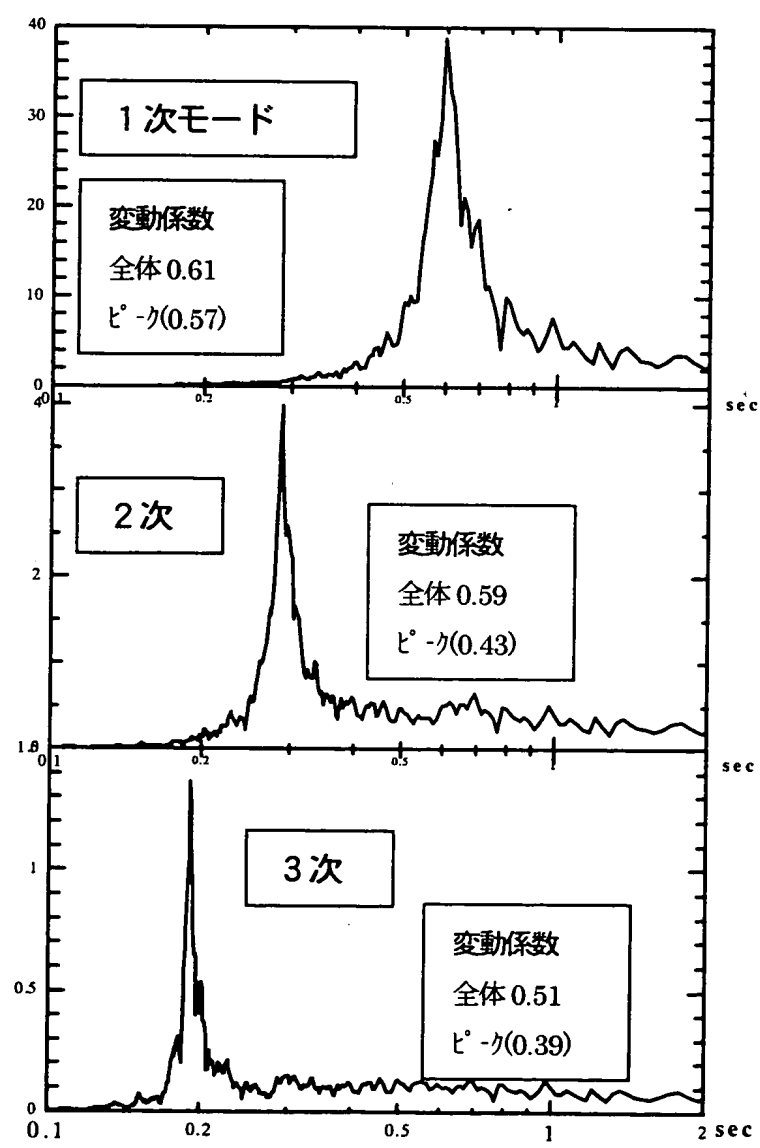

図4.モード振幅のスペクトル

[弾性，モテル 2，10 波の平均値]

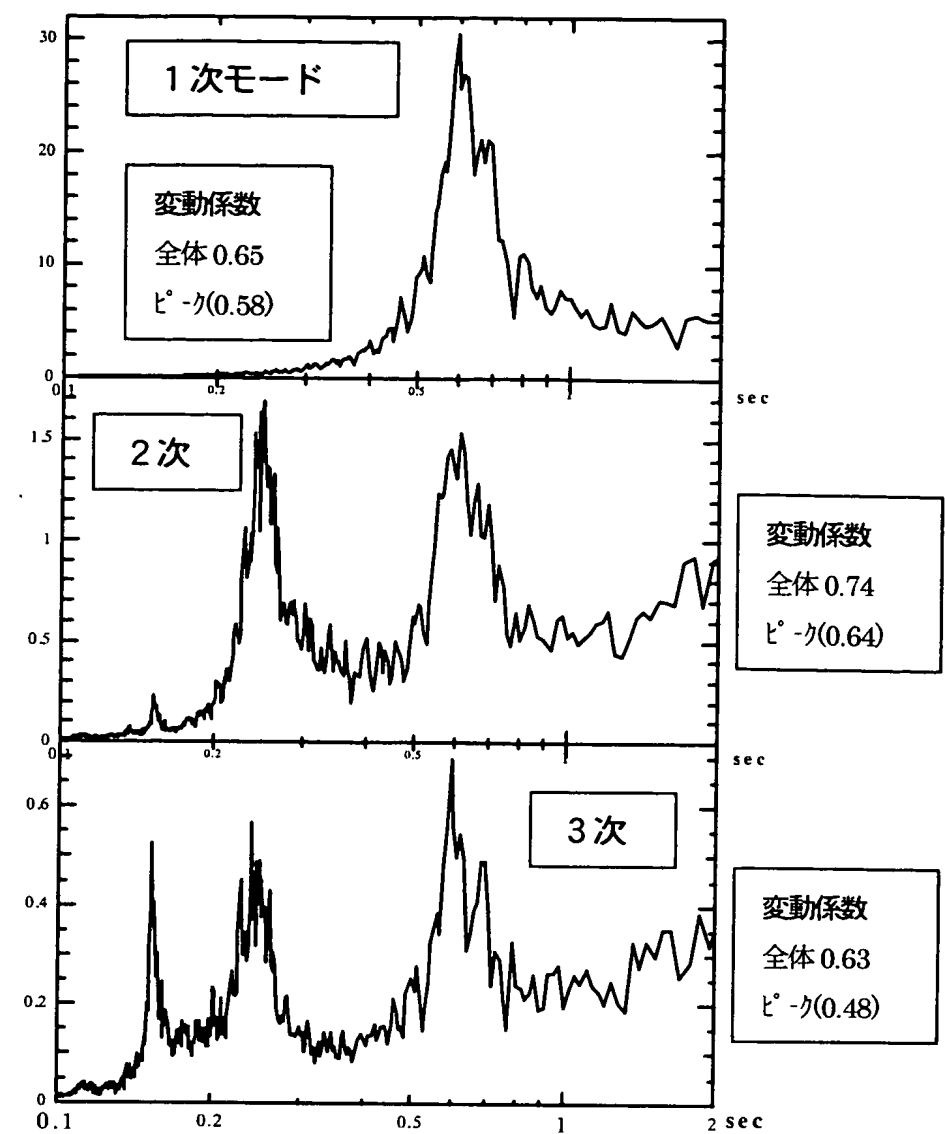

図 3. モード振幅のスペクトル

[弹塑性, モデル 1,10 波の平均值]

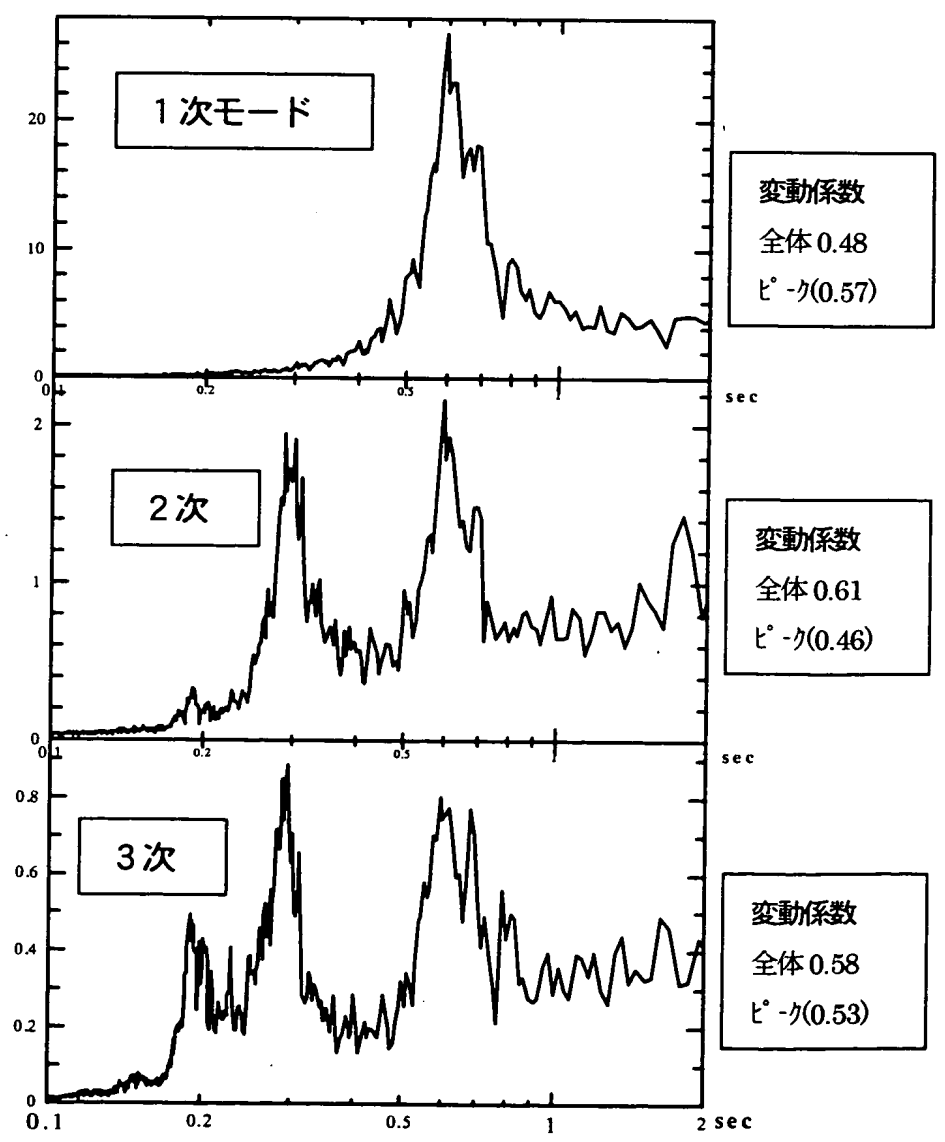

図 5. モード振幅のスペクトル

[弾塑性, モデル2，10波の平均值] 
3.4 モード振幅 $\left\{{ }_{s} a(t)\right\}$ の特性

a）10 波の地震応答記録による統計的性質

図 $2 \sim 5$ に3. 2 の地震応答記録 $\{y(t)\}$ を使って求めたモード振幅 ${ }_{s} a(t)$ のフーリエ振幅スペクトルを示す。モテル $1 ， 2$ の弾性, 弾 望性のそれぞれについて，10波の地震忘答記録によるスペクト ルの平均を示している。スペクトルの各周期における変動係数の 平均は, モテル 1 の弾性で0. 61 , 弾塑性では 0.65 , モデル 2 では 弾性で 0.61 , 弾塑性では 0.48 となっている。

また，全時間（40秒）の記録を用いた本方法のスペクトルのピー ク値を表 1 に示す。さらに, 比較のためモデルの弾性周期及び等価 線形化周期を同表中に示した。等価線形化周期 $T_{e}$ として, 各モテル

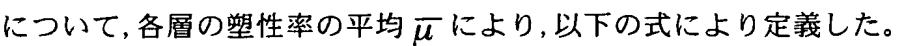

$$
\begin{array}{lll}
T_{e}=\sqrt{\bar{\mu}} \times T & \cdots . .(4) & \text { [等価線形化 1] } \\
T_{e}=\sqrt{0.7 \bar{\mu}} \times T & \cdots \cdots(5) & \begin{array}{l}
\text { [等価線形化 2 ] } \\
\text { ただし } T ; \text { 初期周期 }
\end{array}
\end{array}
$$

弾性応答によるモード振幅 ${ }_{s} a(t)$ のスペクトル

$1 ， 2 ， 3$ 次モードのスペクトルとも，それぞれのピークがはっき りしており, それぞれのピークが, 表 1 のモデルの周期とほほ一致 する。また, 各モードのスペクトルは, 単一のピーク成分を持ち, 他のモードの成分は分離されている。

彈塑性応答によるモード振幅 ${ }_{s} a(t)$ のスペクトル

1 次モードについては, 弾性 1 次周期に対するピークが最も大きく 表れ，塑性化周期のピークはわずかに表れている。塑性化周期は， 個々の地震波のスペクトルでは，かなりよく表れているが，平均化 すると見えにくくなる。

2 次, 3 次モードでは, それぞれ 2 次, 3 次のピークはみえている が，他のモードも残る。また，モテル 1 よりモテル 2 の方が, 他の モード成分が残る割合が多い。

\section{b) 弾塑性 1 次モード振幅の検討}

塑性化による，長周期化をみるために，モード振幅 ${ }_{s} a(t)$ が最大 值を示す時刻の前後 1 秒間のフーリエ振幅スペクトルを求めた。 モテル 1 の地震波 1 の地震底答記録を使って求めた 1 次の弾塑性 のモード振幅スペクトルを図 7 に示す。比較のために, 同じ条件

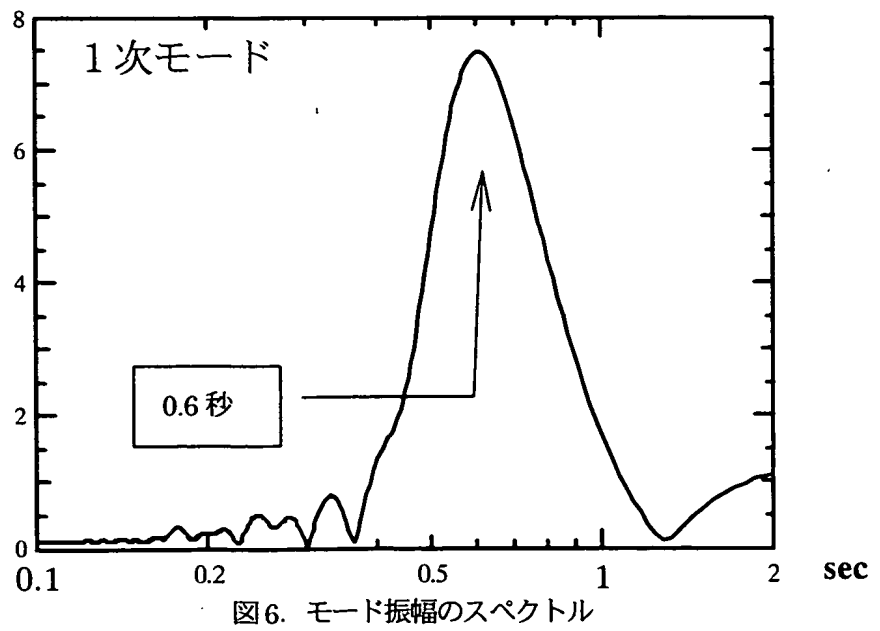

[弾性, モデル 1 ,地震波 $1, ヒ^{\circ}$-ク士 1 秒]
で求めた弾性のモード振幅スペクトルを図 6 に示す。図 6 の弾性 スペクトルには，モテルの 1 次周期の 0.6 秒がピークとして表れ るのに対し，図 7 の弾塑性スペクトルには，モテルの 1 次周期の 0.73 秒がピークとして表れる。このことは，最大変形近傍の 1 次 モードスペクトルのピークと, 表 1 の等価線形化周期 2 が対応し ていることを示している。

\section{4. まとめ}

本方法による弾塑性モード解析方法を使用して，異なる2つのモ テルについて，10 波の地震応答記録により弾性・弾塑性モ一ド解 析を行い, 弾塑性応答時のモード形・モード振幅の平均および変動 関数スペクトルについて示し，統計的に考察した。

さらに最大変形近傍での弾塑性応答によるモード振幅から，その スペクトルを使い塑性化周期の検討を行った。

本方法を使うことにより，弾塑性多質点系モデルの塑性化周期の 伸びを明らかにすることができ，塑性時の等価線形化周期を推定す ることができた。今後は，さらに異なる種類の応答量や塑性応答レ ベル等について検討を進めたい。

\section{参考文献}

1）益野英昌，柴田明徳：层害建物をモデルとした弹塑性地祳店答のモード 解析, 日本建築学会大会学術譜演梗概集B-2構造 II , pp. 391 392, 1998. 9.

2）益野英昌，柴田明徳：モード分解に基づくペントハウスを有する建物の

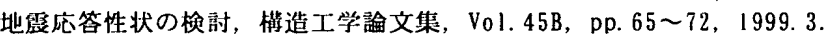

3）益野英昌，柴田明德：震害建物をモテルとした弹塑性地很庆答のモード 解析（その 2)，日杫建築学会大会学術講演梗概集B-2構造 II, pp. 469 $\sim 470,1999.9$.

4）滝田貢，飛田澗，毛呂兵，伊藤敬一：多点同時記録による応答モードの

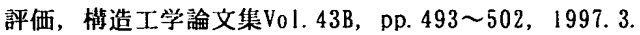

5）益野英昌，柴田明徳：多質点系の応答記録に基つくく弹型性モード解析， 日本建築学会大会学術满演梗蔇集B-2檴造 II pp. 485 486, 2000.9.

6）噇澤春男, '関弘義 : 架模の塑性履歷応答結果に対するモード分解手法と その意義，掅造工学論文集，Vol. 32B，pp. 89〜100，1986. 3.

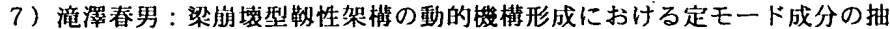
出菁造工学論文集，Vol. 36B， pp. 245 258，1990.3.

8 ）益野英昌，柴田明徳，小川淳二，淥谷純一： R C 造震害建物の応答解析 に基づく付加棈造物の制震効果の检討，棈造工学論文集，Vol. 44B， pp. $295 \sim 300,1998.3$.

9) 益野英昌，柴田明德：多質点系の応答記録に基つくく弹塑性モード解析（そ の 2 ），日本建策学会大会学術犝演梗概集B-2棈造 II, pp. 535～536, 2001. 9 .

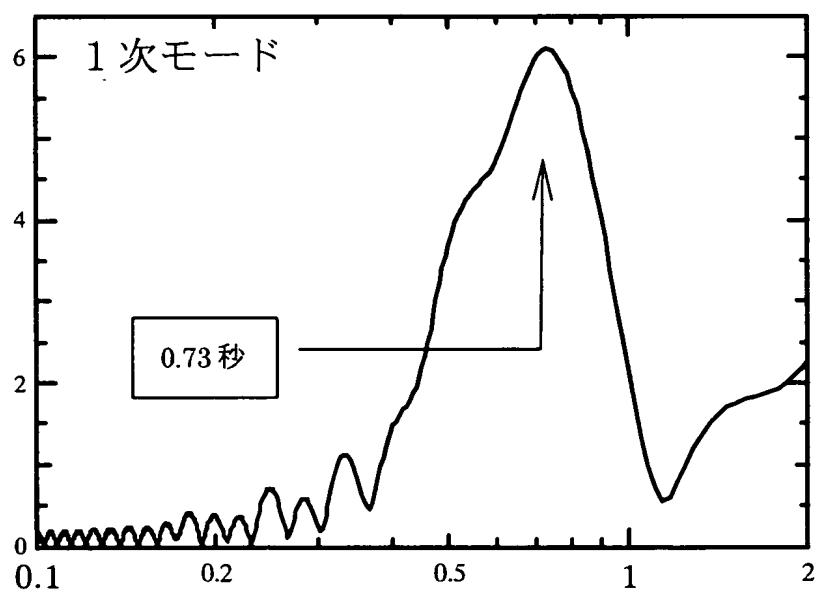

sec

図 7.モード振幅のスペクトル

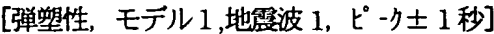

[2001年10月11日原稿受理 2002年 2 月18日採用決定］ 